\title{
Slowly Learning the Hard Way: U.S. America's War on Drugs And Implications for Mexico
}

\author{
Glen Olives Thompson*
}

\section{ABSTRACT}

U.S. America's aggressive drug enforcement policy, costing over US $\$ 1$ trillion and putting millions of people in prison for casual drug use, is an abject failure. By regulating drug use rather than criminalizing it, per capita recreational drug use in the United States would be the same or even lower than it currently is, safer for consumers, and far less costly to society in terms of socioeconomic harm. This failed policy has not only affected U.S. society in such a harmful way that it almost cannot be overstated, but it has also resulted in quite needless drug cartel violence in Mexico and other countries. Included here is a pragmatic suggestion for reform of U.S. drug policy.

Key words: war on drugs, prohibition, drug use in the United States, drug liberalization, drug decriminalization, drug use studies, U.S. drug policy.

\section{RESUMEN}

La agresiva política de Estados Unidos contra las drogas, con un costo de más de un billón de dólares y millones de personas enviadas a prisión por consumo casual de drogas ha resultado un fracaso absoluto. Regularizar el consumo de drogas en lugar de criminalizarlo daría como resultado un consumo per cápita de drogas recreativas igual o incluso menor al que existe actualmente, más seguro para los usuarios y con daños mucho menos costosos en términos socioeconómicos. Esta fallida política no sólo ha afectado a la sociedad estadunidense de una manera tan dañina que ni siquiera podría exagerarse, sino que ha generado una violencia completamente innecesaria entre los cárteles de la droga en México y otros países. Se ofrece en este artículo una sugerencia pragmática para reformar las políticas estadunidenses en la materia.

Palabras clave: guerra contra las drogas, prohibición, consumo de drogas en Estados Unidos, liberalización de las drogas, despenalización de las drogas, estudios sobre el consumo de drogas, políticas públicas contra las drogas de Estados Unidos.

\footnotetext{
* Professor of North American law (United States and Canada), La Salle University, Chihuahua campus, tolives.glen@gmail.com.
} 
In the grand scheme, [the War on Drugs] has not been successful; 40 years later, the concern about drugs and the drug problem is, if anything, magnified, intensified. Gil Kerlikowske, U.S. Drug Czar (AP, 2010)

\section{INTRODUCTION}

By way of background, some time ago I published an academic paper focusing on the legal uncertainties regarding conflicts between state and federal laws with regard to California's decriminalization of medical marihuana (Olives, 2012: 55). The research for the article necessarily required a great deal of reading about U.S. drug policy and encompassed such diverse disciplines as science, medicine, the social sciences, law, politics, and religion. As I said then, the research proved to be an object lesson for both scholars and students on the importance of interdisciplinary studies. But due to the specialized legal focus of that paper (state and federal conflict of laws as discussed in recent U.S. Supreme Court cases), much of my research was not used; it is, however, interesting and surprising in its own right, and I think it bears sharing.

Illegal and legal drug use is hardly ever ignored by the news cycle. Most recently, Uruguay legalized marihuana, and U.S. state of Colorado legalized the recreational use of marihuana, joining 22 other states that have either legalized or decriminalized it for various uses (Governing Outlook, 2014). ${ }^{1}$ Television and print media have been overrun with both proponents and opponents debating drug policy liberalization in the United States. Unfortunately -and expectedly-, these debates tend to be heavy on personal opinion and light on hard empirical evidence. Nonetheless, we are currently undergoing a sea change in public opinion about illegal drug use, and there is a trend in the United States for not only decriminalizing some classes of drugs such as marihuana, but also legalizing them.

Almost all of us are psychoactive drug users. ${ }^{2}$ Whether you enjoy a beer (the active ingredient, alcohol, is a central nervous system depressant), or a cup of coffee (the active ingredient, caffeine, is a central nervous system stimulant), or a pain pill for your bad back (usually an opioid derivative), we ingest drugs every day. And

\footnotetext{
${ }^{1}$ For the sake of clarity and simplicity, throughout this paper I use the term drug liberalization, which encompasses drug legalization, re-legalization, or decriminalization, whether for medical, recreational, or other uses.

${ }^{2}$ A psychoactive drug (psycho-pharmaceutical or psychotropic) is a chemical substance that crosses the blood-brain barrier and acts primarily on the central nervous system where it affects brain function, resulting in alterations in perception, mood, consciousness, cognition, and behavior. See, for example, "Alcohol and Other Drugs" (Northern Territory Government, 2008).
} 
some people abuse them. This has been true since the very beginning of human civilization, and if history is any guide, it is unlikely to change. Historical evidence, for example, suggests that the world's first civilization, the Sumerians, had a real fondness for opium as early as 5000ВС (Lindesmith, 1965: 204), and archaeological evidence points to earlier primitive hunter-gatherers drugging themselves with certain plants (Merlin, 2003: 323, Escohotado: 1999: 7). Even animals like African elephants and North American birds consume drugs (either fermented fruit containing alcohol or hallucinogenic berries) for no other reason than to alter their consciousness for pleasure, to get high (Samorini, 2000: 12).

For U.S. legislators, making certain psychoactive drugs illegal, regulating others, and leaving still others completely unregulated, requires a difficult balancing act, and an easy one to get wrong, as we shall see.

We regulate the sale of alcohol, for example, by prohibiting minors from purchasing or consuming it, stipulating where and when it can be sold, and formulating rules for its purity and safe manufacture, among many other things. Ostensibly, this is because alcohol has potentially deleterious effects when drunk in excess, such as the impairment of motor skills and good judgment, plus poor health consequences, potentially leading to death or injury not only for the drinker, but people he/she may come into contact with, in addition to increasing public health costs to taxpayers. Thus, by regulating this particular drug, we allow for its consumption while putting up safeguards, balancing, as it were, individual freedom with the collective safety and wellbeing of society. ${ }^{3}$ And this seems to be an entirely reasonable approach to the drug of alcohol, and one could even argue that it is currently underregulated, as it remains the third highest preventable cause of death in the U.S. (Centers for Disease Control, 2011). ${ }^{4}$ Illicit drug-related deaths, by comparison, are almost at the bottom of the list for preventable causes of death (Mokdad et al., 2004: 1242), reserving marihuana-related causes of death for last place, with 0 fatalities reported so far (Gable, 2006: 207; Paulozzi, 2006: 1755-1757). ${ }^{5}$ In fact, the best available research indicates clearly that, in terms of harm to both individuals and society, alcohol is far more harmful than either heroin or crack cocaine (Nutt, King, and Phillips, 2010:

\footnotetext{
${ }^{3}$ At the other end of the political spectrum, the Libertarian Party's official position on drug policy is that all drug laws should be repealed (Libertarian Party, 2008). Their philosophical argument (not directly addressed in this article) is that what one does to ones' own body should never be subject to criminal prosecution. For example, we do not prosecute people who have attempted suicide for attempted murder, although we could under most criminal statutes. Why then, the rhetorical argument continues, should we prosecute people for what substances they choose to ingest?

${ }^{4}$ This statistic combines not only direct deaths caused by alcohol, such as acute alcohol intoxication and cirrhosis of the liver, but also alcohol-related deaths, such as motor vehicle accidents, homicides, etc.

${ }^{5}$ Of the 38239 overdose deaths reported in 2010, the vast majority were from legal pharmaceutical drugs (22 134 deaths).
} 
1558-1565). It would seem, then, at the very least, that other drugs such as cannabis, opiates, cocaine, hallucinogens, and other classes of drugs should be regulated in a similar manner to alcohol, especially since the individual use of many currently illegal drugs like cannabis have far fewer negative health and societal effects than alcohol, as studies confirm (Goode, 2008: 116-128). (Unless, of course, if liberalizing the laws covering these drugs would result in the proliferation of drug addiction; as argued below, however, this would be an unlikely result.) Yet these drugs have remained illegal despite the scientific and sociological evidence of their comparative benign impact on individuals and society. Why? The answer lies in a somewhat bizarre accident of history and politics.

\section{The First War on DRUGS: Alcohol Prohibition in the United States}

From 5000BC until the AD1920s, not many people seemed too concerned about psychoactive drugs, as there simply were not many laws on the books making them illegal. Then, in the United States, after a campaign dating back to 1907, certain religiously pious Protestant sects finally convinced Congress of the evils of drunkenness, and marshaled enough votes to amend the U.S. Constitution (Eighteenth Amendment [1919], repealed by the Twenty-first Amendment [1933]) and prohibit the sale, consumption, and transportation of all alcohol. What followed was a national disaster. Drinkers did not stop drinking because alcohol was illegal. They just bought their beer or gin from a different source, the black market. Bootleggers and gangsters such as $\mathrm{Al} \mathrm{Capone} \mathrm{saw} \mathrm{the} \mathrm{profit} \mathrm{to} \mathrm{be} \mathrm{made} \mathrm{in} \mathrm{black} \mathrm{market} \mathrm{alcohol,} \mathrm{and} \mathrm{took} \mathrm{advantage}$ of an enormous untaxed business opportunity provided by Prohibition (Blocker, Fahey, and Tyrrell, 2003: 23). The U.S. mafia was born. Violent clashes between rival gangs vying for territory, and between the police and these gangs, turned into a lowgrade internal war where thousands of lives were lost -not at all dissimilar from rival gang wars in the U.S. or the narco turf wars in Mexico. Not surprisingly, the homicide rate increased drastically during Prohibition and fell drastically after it was repealed (U.S. Bureau of the Census, 1975: 414) despite economic hardships brought by the Great Depression. Equally important is the surprising fact that while alcohol consumption initially dropped during the first years of Prohibition, in a few years it increased to 70 percent above pre-Prohibition levels (Miron and Zwiebel, 1991: 242; Thornton, 1991) despite being illegal. By prohibiting the production and consumption of alcohol, its use increased, as did violent crime, which is not, I suspect, exactly what the government had in mind when the law went into effect. 
After 13 years of gun battles with bootleggers and gangsters, and citizens openly drinking alcohol in defiance of the law (including law enforcement officials charged with enforcing it), Prohibition was repealed. The grand experiment proved to be an epic failure. Suddenly, tax money from alcohol sales poured into the accounts of the federal and state governments, quality standards of alcohol products were promulgated and enforced, and regulations were put in place enforcing things such as the minimum age to purchase and consume alcohol, the labeling of alcohol content, and restrictions on marketing activities, among many others. It is universally agreed by historians, politicians, and the public at large, that Prohibition was an enormous blunder. But, for reasons explained in the next section, the U.S. Congress learned little from this mistake. Perhaps Georg Wilhelm Friedrich Hagel was correct when he said, "We learn from history that we do not learn from history."

\section{The Current War on Drugs: History and Consequences}

Marihuana provides a good base for the discussion of drug liberalization since it is the most widely used illegal drug in the U.S. (USDHHS, 2011). Since before the founding of the nation, marihuana played an important role in the economy; in 1619, for example, the Jamestown colony legally required all settlers to grow cannabis for rope production, and later George Washington grew cannabis as one of his primary crops (Deitch, 2003: 16; Dvorack, 2004). Then, in the early 1900s certain states began regulating cannabis production and consumption. The movement to prohibit drugs such as marihuana was initiated, again, by politicians, but not for religious reasons this time. It was based on the ugly combination of economics and anti-immigrant sentiment. The state of California provides a good example. California's prohibition of marihuana, which led to its prohibition in other states, is closely linked to agricultural competition with Mexico (Maisto, Galizio, and Connors, 2007: 426-431). Specifically, much of the cannabis imported into the state came from Mexico (often referred to as "loco weed") and was widely used by migrant farm workers (2007: 431). Combined with immigrant tensions and competition between small U.S. American (and politically influential) farmers and larger corporate farms using cheaper Mexican labor, a whole host of drug laws was created that made illegal not only Mexican marihuana, but also Chinese opium dens and hashish (concentrated cannabis), traditionally used by Sikh Indian immigrants (2007: 436). Around the same time, Astorga (2003) points out that Mexican legislators were proposing restrictions on marijuana, cocaine, and opium for moral and health reasons, despite the fact that use of these 
drugs by Mexicans was relatively uncommon; interestingly, Mexican drug laws also had a significant xenophobic element. But one cannot pass a law making a drug illegal if it is simply bad for you: a myriad of things have deleterious effects on society, such as having a poor diet or smoking cigarettes or drinking too much or cheating on your spouse, but these activities are entirely legal. To justify making a particular drug illegal to possess or consume, it has to be more than bad for you, it has to be extraordinarily dangerous, evil, even immoral.

The height of irony is that, at the time that the U.S. government was conceding that Prohibition simply was not working and the long experiment making the drug alcohol illegal was coming to an end, the head of the Federal Bureau of Narcotics, Henry J. Anslinger, was claiming disingenuously (for the very reasons set forth in the last sentence of the foregoing paragraph) that marihuana was causing people to be overly sexual, go insane, act irrational, and commit violent crimes (McWilliam, 1990: 183). Posters and film reels were widely distributed warning citizens to beware of marihuana because it would lead to "murder, insanity, and death" (McWilliam, 1990: 184). Over the next 40 years, various federal laws were passed restricting, regulating, and levying taxes on many classes of drugs (Olives, 2012: 56.) Then, with the dawn of the 1960s, marihuana became synonymous with counter-culture revolution, threatening the culturally conservative ruling political class. And conservative thenPresident Richard Nixon was having nothing of this nonsense.

In 1970, Congress passed the Comprehensive Drug Abuse and Control Act (Pub. L. No. 91-513, 84 Stat. 1236), which, among other things, classified drugs into categories of harmful and potential benefits. Marihuana was placed into Schedule I along with heroin: the most dangerous drugs with no medical benefits. The following year, President Nixon signed the act, and in a nationally televised speech to Congress, declared his War on Drugs. Nixon's War on Drugs was a brilliant political move and not only resulted in his landslide reelection in 1972, but also-and unfortunately-led to many other international leaders copying his "tough on drugs" strategy (Wodak, 2012: 1). Funded by U\$100 million in federal monies, resources poured into state, local, and federal law enforcement coffers around the nation. New police and federal agents were hired, and prisons began filling up with non-violent drug offenders, with new prisons seemingly popping up overnight to accommodate the subsequent overcrowding. The result? Currently, the United States has the highest incarceration rate of any country in the world at 0.743 percent of its population, far exceeding both Russia and China (International Centre for Prison Studies, 2010). In 1985, around 41000 people were incarcerated per year in federal prisons for drug-related offenses; in 2010 that number exceeded 500000 per year (Alexander, 2010: 62). Drug-related charges account for more than one-half of the rise in state prison populations (2010: 63). 
Shockingly, 31 million people have been arrested for drug-related charges since the War on Drugs began (2010: 64).

Since 1970, we have spent more than US\$1 trillion on this drug enforcement effort (AP, 2010). When a country has a prison population approaching one percent of its residents, most of whom are incarcerated for non-violent, drug-related crimes, spends billions of dollars a year on drug enforcement and prison related activities, and yet has the highest rate of illegal drug use of any country in the world (Warner, 2008), something is deeply out of balance. And the social cost to otherwise law abiding and productive citizens jailed for recreational drug use is immeasurable: families separated, casual drug users branded with the scarlet letter of felons, lost jobs, lost lives.

Anti-drug supporters will say that this is the price we have to pay for a drugfree, sober, and productive society. But the data do not support this view. Not only has drug use remained essentially unchanged since the war began, particularly with "soft" drugs like marihuana (WDR, 2013), but drugs are much more potent and much cheaper than they have ever been. According to a study conducted by the British Medical Journal Open,

In the United States, the average inflation- and purity-adjusted prices of heroin, cocaine, and cannabis decreased by 81 percent, 80 percent and 86 percent respectively between 1990 and 2007, whereas average purity increased by 60 percent, 11 percent, and 161 percent respectively. Similar trends were observed in Europe, where during the same period the average inflation-adjusted price of opiates and cocaine decreased by 74 percent and 51 percent respectively. In Australia, the average inflation-adjusted price of cocaine decreased 14 percent, while the inflation-adjusted price of heroin and cannabis both decreased 49 percent between 2000 and 2010. During this time, seizures of these drugs in major production regions and major domestic markets generally increased. (Web, Kerr, Nosyk et al., 2013: 2)

This sobering -no pun intended-study is testament to the awesome power of economic supply and demand. And even when particular drug interdiction efforts cause a temporary price spike, drug users are not particularly price-sensitive, so demand is seldom affected, and drug dealers end up benefiting, as two prominent scholars point out in their economics textbook:

The more effective prohibition is at raising costs, the greater are drug industry revenues. So, more effective prohibition means that drug sellers have more money to buy guns, pay bribes, fund the dealers, and even research and develop new technologies of drug delivery (like crack cocaine). It's hard to beat an enemy that gets stronger the more you strike against him or her. (Cowen and Tabarrok, 2009: 60) 
In 2010, an estimated 17.4 million U.S. Americans reported using marihuana in the past month according to the annual National Survey on Drug Abuse and Health (USDHHS, 2012). And one should not make the mistake, as many are prone to do, of thinking that illicit drug users are mainly the socially downtrodden, poorer, and ethnic minority classes. Political elites like their drugs, too. United States Presidents George Washington, Thomas Jefferson, James Madison, James Monroe, Andrew Jackson, Zachary Taylor, Franklin Pierce, Abraham Lincoln, John F. Kennedy, Jimmy Carter, George W. Bush, Bill Clinton, and Barack Obama all used marihuana (Deitch, 2003: 16; Schlosser, 2003). Both George Bush and Barack Obama used cocaine as well. If I were to expand the this list to include all high level public officials, Supreme Court justices, Nobel Prize winners, world business leaders, scientists and academics, it would fill another three pages. Curiously, in the face of this growing body of evidence, organizations such as the United Nations Office on Drugs and Crime publish statements such as, "We have to admit that, globally, the demand for drugs has not been substantially reduced and that some challenges exist in the implementation of the drug control system" (WDR, 2013: iii). With this statement, the UN has brought the art of sugarcoating inconvenient facts to a whole new level.

The parallels between the prohibition of alcohol and the War on Drugs are striking. I previously mentioned that alcohol consumption in the United States increased during Prohibition. This was because of a very simple economic rule: the prohibition of wildly popular products, especially addictive products such as alcohol and other drugs, simply does not work. Indeed, it often has the opposite effect, and results in proliferation. Consider the following: it is easier and more dangerous for a teenager to purchase marihuana, cocaine, crack cocaine, heroin, and almost any other illicit drug, than to buy a beer or a pack of cigarettes (Armentano, 2009). This is, of course, because drug dealers do not bother with IDs, and are not especially concerned with quality control. As with alcohol, time and time again studies (see below) as well as direct observation (the history of alcohol Prohibition, above) have proven that if you regulate and control a drug rather than criminalize it, its use will remain the same or in many circumstances go down. To further drive the point home, consider that both Portugal and the Netherlands, where virtually all drugs have been liberalized, have drastically lower per capita rates of drug use than the United States (WDR, 2013). Moreover, the U.S. government's anti-drug propaganda is making matters worse, not better. Campaigns by the Partnership for a Drug-Free America and other anti-drug organizations, which are largely funded by alcohol and pharmaceutical companies, continue to propagate misleading information about drugs that is contradicted by science (Seaborne, 2012; Earlywine, 2002: 69; Gable, 2006: 290). Even some of the people entrusted to enforce U.S. drug laws are against them. Law Enforcement Against 
Prohibition (LEAP) is a group of law enforcement professionals, both active and retired, who openly lobby for liberalization of drug laws and publish annual reports of drug use statistics in the United States. ${ }^{6}$ They know all too well that the War on Drugs, by any reasonable measure using any statistic you like, has been an abysmal failure. There is no way anyone can say that the war has been won, has been even moderately successful, or has even made infinitesimal progress. Saying so is tantamount to saying that General Custer won the battle of Little Bighorn. Most recently, one anti-narcotics officer, in describing his 26-year career in law enforcement, said, "I did more harm than good, and the harder my colleagues and I tried, the more damage we did" (Cole, 2014).

So, why has Congress not repealed the War on Drugs and replaced it, as the Prohibition-era Congress did, with something more sensible and pragmatic, namely regulation and control? The answer comes in the form of a trifecta with immense power: money, propaganda, and counterintuitiveness.

As Judge James P. Gray famously said, "The War on Drugs is not winnable, but it is eminently fundable." ${ }^{7}$ Once the government establishes a multitude of federal and state agencies to accomplish a mission with billions of dollars in funding, creating thousands of well-paying jobs -starting salaries, for example, of new federal Drug Enforcement Agents is around US\$60 000 per year-, how do you tell them that the war is not working and they are no longer needed? If you want to keep your political office, at the municipal, state, or federal level, you don't. The lobbying effort from police unions, pharmaceutical companies, alcohol and beer companies, prison guard unions, and communities that depend on these jobs, is too great a mountain to climb (Fang, 2012). Second, because we have for so long been bombarded with the anti-drug propaganda on the evils of drug abuse, politicians who advocate for drug liberalization are quickly branded as "soft on drugs" or "pro drug use" making a drug liberalization platform the true third rail of U.S. politics, as evidenced by the political ineffectiveness of the Libertarian Party and its entire lack of members in both houses of Congress. The third reason that U.S. federal drug policy has not been liberalized is that asserting that fewer drug laws will not result in more drug users is deeply counterintuitive. We tend to automatically assume that harsh punishments and rigorous enforcement for any crime will naturally result in a reduction of that crime, but studies have almost consistently shown that this is not the case; indeed evidence

\footnotetext{
${ }^{6}$ The fact that if they get their way (drug liberalization) many of their members will be at risk of losing their jobs is testament to their commitment to their position. See, for example, their website (LEAP, 2012).

${ }^{7}$ Judge Gray, a U.S. jurist who has seen first-hand the absurdity of the War on Drugs in his California courtroom, made this comment many times, most recently at the University of Texas at El Paso, during the Global Policy Forum on the War on Drugs in 2009. The conference summary is available at U.S. War on Drugs 1969-2009 (2009).
} 
suggests that while enforcement may be effective for purposes of punishment and rehabilitation, it has only very mixed results with regard to crime prevention (Tonry, 1995: 116-22). Of course, many things in human experience are counterintuitive, such as the fact that the Earth revolves around the Sun and that we live on a sphere spinning at thousands of miles an hour through the cosmos; but through science we know this to be true, although it may be impossible for us to feel that it is true. Alas, as a society, we have not yet digested the counterintuitive truth of our criminal justice system, and in particular as it relates to drug prohibition.

\section{Analysis of Comparative Data on Drug Use And ENForCEMENT EXPENDITURes in Liberal Versus Strict ENForcement JuRISDictions}

With the lesson of alcohol Prohibition as a guide, it seems highly unlikely that drug liberalization will lead to drug proliferation. Nobody is bootlegging moonshine anymore. Why would you? Simply open a licensed, regulated liquor store, distillery, restaurant, bar, or winery, and make your money legally. Would any serious person rather sell drugs on the black market, risking life and limb, when you can sell drugs legally, at a handsome profit, even becoming an upstanding member of your local Rotary Club? Perhaps Harry Browne, a prominent Libertarian politician said it best:

There are no violent gangs fighting over aspirin territories. There are no violent gangs fighting over whisky territories or computer territories or anything else that's legal. There are only criminal gangs fighting over territories covering drugs, gambling, prostitution, and other victimless crimes. Making a non-violent activity a crime creates a black market, which attracts criminals and gangs, which turns what was once a relatively harmless activity affecting a small group of people into a widespread epidemic of drug use and gang warfare. (Olivier, 1999) ${ }^{8}$

Yet we need not rely on historical facts alone. A great deal of data has been collected and studied with regard to countries that have liberalized their drug policies. In some of the most recent examples, it is too early to tell what the effects might be due to the lack of data. ${ }^{9}$ Others, however, prove instructive. In 2001, Portugal abol-

\footnotetext{
${ }^{8}$ In fairness, it is arguable that crimes such as prostitution are "victimless," but Mr. Browne's Libertarian philosophy is firmly centered on individual liberty, again in keeping with the tradition that no government should have the authority to regulate what one does with ones' own body.

${ }^{9}$ For example in 2010, the Czech Republic liberalized its drug laws, making simple possession of drugs a
} 
ished all criminal penalties for personal drug possession. In the five years after the start of liberalization, drug use by teenagers declined; the rate of HIV infection among drug users dropped; deaths related to heroin and similar drugs were cut by more than half; and the number of people seeking treatment for drug addiction doubled (Greenwald, 2009: 11-19). With regard to cannabis, as a percentage of the population aged 15 to 64 who have consumed at least once in the past year, Portugal's rate was 3.3 percent, while the United States, where cannabis remains a Schedule I highly illegal controlled substance under federal law, usage is at 13.7 percent. The trend is similar with cocaine use as well, with U.S. cocaine use around 2.8 percent (the highest of all countries surveyed) and Portugal at 0.3 percent (WDR, 2011 and 2013). ${ }^{10}$ The broader data, however, is even more instructive. In a 2008 World Health Organization study, the United States, despite its stringent federal anti-drug laws, found that U.S. Americans have the highest level of illegal drug use of all countries surveyed, far exceeding levels of drug use in countries with liberal drug policies such as the Netherlands (Warner, 2008).

To restate the evidence as succinctly as possible: jurisdictions that treat drug use and addiction as a public health problem and not as a criminal problem, thus regulating drug sales rather than criminalizing them, have benefited from lower drug use rates, higher drug rehabilitation rates, lower public health care costs, and fewer public funds squandered on "drug enforcement."

There are, of course, some countries that have stricter drug laws than the United States. In Singapore, for example, 400 people were publicly hanged for drug possession between 1991 and 2004; and perhaps not surprisingly, Singapore does have a very low rate of drug use, undoubtedly because of their draconian drug laws (Kent, 2013). But this fact merits the making of a couple of points, however pedestrian they may be. The first is that not even the most passionate anti-drug supporter is seriously advocating killing casual drug users. The second is that the fact that people are still using drugs in Singapore even under the threat of death is a telling testament to the futility of prohibition. (Similar examples of the ineffectiveness of draconian drug laws can be found in other countries such as Saudi Arabia and Iran.)

misdemeanor subject to a small fine; but data on drug use since the implementation of the law is as of yet unavailable; and, as mentioned, Uruguay legalized marijuana just this year.

${ }^{10}$ The data collected by the United Nations Office on Drugs and Crime and compiled as the World Drug Report are reported for 2007 in the case of Portugal and 2009 in the case of the United States. Note that statistics on drug use and expenditures for enforcement, whether produced by academics, governmental agencies, think tanks, or NGOS, are published irregularly, and often information for specific jurisdictions is not available for corresponding years in other jurisdictions, making an exact correlation of data per year difficult. I have made every effort, therefore, to compile the most recent data available within the closest time frames. 
To balance the argument along an opposing vein, the liberalization of drug laws have been botched as well, resulting in proliferation and increased drug abuse. The most notable of these is the 1965 "Stockholm Experiment," initiated by the Swedish government, where amphetamines and opiates were legally prescribed by doctors to a small group of patients in any dosage they requested, many of whom then supplied these drugs to friends or sold them, eventually leading to a rise of intravenous drug use. The now apparent -and glaring- fault of the experiment was that the group of patients enrolled in the program was only 150 at its height (un Office on Drugs and Crime, 2007: 13). As one might expect, the liberalization of a certain class of drugs for 150 people had no effect on the illegal drug market of an entire nation, indeed it only supplemented it; in short, the experiment failed for the reason that it was just that: an experiment, not a comprehensive social and public health policy. The anti-drug liberalization backlash that resulted led to Sweden now spending a half of a percent of its GDP on drug enforcement annually (roughly US\$276 million in a country with a population of less than 10 million); it has roughly the same druguse rates as its European neighbors, depending on the drug in question, putting Sweden anywhere from the middle of the pack to the lower one-third for the number of illegal drug users (un Office on Drugs and Crime, 2007: 53-74; Hallam, 2010: 4). Hardly a resounding success given the public monies thrown at the problem. Plainclothes Swedish police regularly patrol nightclubs and bars looking for people who might be under the influence of drugs and have the authority to stop and search people without probable cause and to force drug testing against citizens' wishes and without a warrant (Hallam, 2010: 7). In contrast, Greece, with a population of slightly over 11 million, spends only about US\$72.5 million on drug enforcement (EMCDDA, 2008: 13), but consistently enjoys fewer drug users than Sweden for every drug surveyed (un Office on Drugs and Crime, 2007: 53-74). Notably, Portugal, which does not prosecute drug users and has the same population as Sweden, regularly falls within the same quartile as Sweden with regard to drug usage as a percentage of the population (2007: 53-54), despite spending less than one-tenth of what Sweden spends on drug-related enforcement (EMCDDA, 2008).

This all raises the question, indeed a question deserving of a good raising: In societies where drug policy is based on criminal prohibition rather than public health, what are residents of these countries really getting? In the case of Sweden, very little. In the case of the United States, nothing. According to the U.S. Department of Health and Human Services, drug abuse and dependence as a percentage of the U.S. population in 2010 is essentially the same as it was in 1970 (2011), despite drug enforcement expenditures of approximately US\$1 trillion (Groff, 2012). While it is true that U.S. residents have the greatest affection for ingesting drugs among countries routinely 
surveyed for drug use statistics, the U.S. now spends an average US\$24 billion per year on drug enforcement activities (Office of National Drug Control Policy, 2013), with nothing substantively positive to show for the effort.

\section{Piecemeal Political Solutions}

Having said all this, I must admit that while I have laid out the problem, I have not been able to find an easy solution in the current political climate. While politicians do exist who are willing and able to challenge the conventional wisdom on drug enforcement in the U.S. -Barney Frank [D-Mass.] comes to mind-, they are, for the economic, political, and psychological reasons stated above, in the distinct minority. Scientists and researchers, meanwhile, continue to lament the ignorance -in many cases willful ignorance- of politicians when it comes to drug use and drug use policy (Wodak, 2012: 2). Of course, the sensible thing to do would be to repeal the Comprehensive Drug Abuse and Control Act and replace it with liberalized drug policy where most drugs would be regulated and controlled like alcohol and tobacco. Billions of dollars could be saved, millions more earned through federal and state taxes, and many millions more, formerly spent on drug prosecution offenses, could be spent on drug education and rehabilitation, a true win-win situation. As noted, other jurisdictions that have done this have enjoyed a decrease in drug use and decreased rates of incarceration, while at the same time benefitting from an increase in tax revenue from legal drug sales (see the California example, below), not to mention a decline in public health costs and increased numbers of people seeking drug rehabilitation. But the sensible thing to do is not always the politically viable thing to do. While I do suspect that the laws nourishing the War on Drugs are doomed to starvation, much like Prohibition of alcohol was doomed to failure, this protracted and costly war will not be lost easily. As the social norms of society change, so must the laws that govern such a society, but unfortunately, this change is likely to be insufferably long. We have been besieged by anti-drug propaganda for so many decades that it has become part of our collective mental furniture. But despite this, new polls suggest that U.S. Americans' views on drug liberalization are changing, with a majority of the population now holding the opinion that drugs such as marihuana should be liberalized (Ellison, 2014). But even if there were a major paradigm shift in the United States' attitude toward drug use, defunding the massive entrenched antidrug bureaucracy, with its sticky tentacles intertwined among federal, state, and local law enforcement agencies, seems to be an extraordinarily unlikely proposition. By way of analogy, a fighter jet can make nimble turns that a jetliner never could; it is 
simply too slow and encumbered by its own inertia. So, too, is the juggernaut of agencies charged with implementing U.S. drug policy.

The eventual decriminalization of currently illegal drugs will take place, to be sure, but it will happen in fits and starts, always taking two steps forward and one step back. Once again, California provides us with a roadmap for how this might happen, albeit for the many reasons stated above, a messy one. Many years ago the penalties for possession of an ounce or less of marihuana were reduced to a minor infraction; in the case of the possession of other drugs such as small quantities of cocaine, the first-time offender is allowed to attend "drug court" where education and rehabilitation takes the place of a prison sentence (Olives, 2012: 60). Then, marihuana was legalized as long as you have a medical prescription, which requires nothing more than asking your doctor for one (65). The problem is that marihuana is still highly illegal under federal law, and users, growers, and distributors are still subject to arrest with harsh prison sentences. The former Bush administration was quite active in federal marihuana prosecutions in California, while the Obama administration has taken a "hands off" approach, citing limited federal funds and the need to prioritize the prosecution of more serious crimes (64). What troubles me is that it anyone's guess as to what approach future administrations will take regarding this conflict. Be that as it may, California has boosted its tax revenue by as much as US $\$ 108$ million annually by taxing the sale of marihuana (MPP, 2013), and this figure does not include local taxes levied by cities and counties.

\section{ImPLICATIONS FOR MEXICO}

As noted above, very few local or transnational criminal organizations bootleg legal drugs such as alcohol or tobacco. Total black market sales of illicit drugs, however, according to the United Nations Office on Drugs and Crime, come to more than US $\$ 300$ billion annually, making it the world's most lucrative business market (Knufken, 2010). Yes, this means that the illegal drug market is more profitable than Microsoft, General Electric, or Telmex. I propose that, based on the historical evidence, had there never been a War on Drugs, had the federal government simply concluded at the end of alcohol Prohibition that all drugs should be regulated in a similar manner, transnational criminal cartels would never have existed, just as gang wars between Budweiser and Heineken never existed. As Luis Astorga has pointed out, transnational drug cartels in Mexico have developed into incredibly sophisticated, albeit clandestine and brutally violent, business operations (2004), as one would expect when the profits generated by operating in the black market are so outrageously high. 
Based on this lesson of history, let us suppose that tomorrow all currently illegal drugs became legal, though regulated and taxed by the governments of the United States and Canada. Further suppose that Mexico, too, ended its prohibition of cultivating marihuana and producing other drugs such as cocaine and heroin and allowed drug exportation along with other legally exportable products. Violent drug cartels competing for territory would no longer make sense when they could export legally. Undoubtedly, competition would continue, but it would be guided by the free market. Marketing your brand of product would focus on quality, flavor, purity, etc. (as with cigarettes and alcohol), which would become the competitive edge of focus, rather than killing your rivals and winning lucrative trafficking routes. Of course, this would greatly depend on a sensible, pragmatic approach by governments. If a government overtaxes and overregulates a particular drug, making it economically prohibitive to purchase legally, consumers will turn to the black market. If, on the other hand, taxes and regulation are reasonable, the consumer will easily avoid the risks of black market purchases and buy through legal channels, even at a premium price. Thus, in the end, public drug policy is really about balancing various interests to find a formula that works, as is done with alcohol and tobacco, acknowledging that a Utopian ideal will never be reached, and a certain percent of the population will always abuse certain substances.

If all of this sounds naïve, consider our current drug policy and its state of utter failure. Pouring more than a trillion dollars into a lost cause with the remote hope that drug use will be reduced is the ultimate in naiveté. And what is more -and is more obvious- is that this strategy has been proven, convincingly I think, to have been an enormous failure, just as the prohibition of alcohol was, while the competing strategy, the liberalization of drug prohibition laws through legalization, regulation, and control, is the only proven game in town for those who are intellectually serious about solving the problem of drug addiction and drug-related violence.

As stated above, the political will does not exist at the federal level to significantly change the United States' drug policy strategy. However, with the high costs of enforcement and incarceration in an anemic economy, together with the potential windfall of new tax revenues, more and more U.S. states are following Colorado's lead with respect to marihuana liberalization and proposing new liberalization laws (Wing, 2013). If this trend continues, it will become increasingly difficult for the federal government to ignore the conflict between federal drug laws and state drug laws, or continue to rely on the doctrine of prosecutorial discretion. ${ }^{11}$ What is likely

\footnotetext{
11 The basic doctrine of prosecutorial discretion allows public prosecutors and police to not arrest and/or
} prosecute some crimes (in this case drug-related crimes) as a matter of convenience; in other words, with 
to happen in the coming decades is that Congress will punt the ball to the states, repealing the Comprehensive Drug Abuse and Control Act, thereby allowing the individual states to promote their own drug policy strategy. Politically this approach may very well be palatable for liberal politicians, who for decades have privately bemoaned the ridiculousness of federal drug policy. Perhaps more importantly, however, many conservative politicians could be sold on the same idea because, while they are generally for stringent drug enforcement, a large portion of conservative political ideology centers on a smaller federal government and more autonomous rights for the states. They could then still claim to be tough on drugs, but also champion states' rights. Having said this, it seems extraordinarily unlikely that this could be accomplished with a single bill, but it could be accomplished in a piecemeal fashion, first by removing marihuana from its current position as a Schedule I controlled substance with ample time for states to determine their own policies regarding marihuana. If successful, other classes of drugs could follow, gradually removing the federal government from drug enforcement, or at least severely limiting its role.

\section{Conclusions}

United States drug policy is a costly, backwards mess in terms of wasted money, socioeconomic harm caused to its residents, and most importantly, its utter uselessness in reducing drug use, drug abuse, and violent crime. Albert Einstein is reported to have said that the definition of insanity is to do the same thing over and over again and expect a different result; under this definition, the War on Drugs is insane. The time-tested answer to this conundrum is to simply reverse course, regulating the sale of currently illegal drugs in much the same way as alcohol and tobacco are regulated. The inevitable result would likely be similar to what Portugal, other countries, and some states that have liberalized drug policies have experienced: reduced drug use, lower public health costs, increased drug rehabilitation, and greater public revenue from taxes. This solution -in principle- is not all that complicated. Implementing this solution within the complex vagaries of U.S. politics, however, is another matter.

Finally, every country has a different culture, political norms, customs, and many other things that make them unique. Clearly, then, a one-size-fits-all approach to drug policy would be inappropriate. The real complexity lies in getting the balance

limited resources and overcrowded court dockets, law enforcement officials may overlook minor criminal activity in order to more actively pursue violent felonies or other high-level criminal activity. This is exactly the approach the Obama administration has taken with respect to medical marijuana in California (Olives, 2012: 60). 
right between individual liberty and the collective wellbeing of society, and as admitted, this is no easy task. It took the United States over 100 years to finally erase the state-sanctioned malignancy of racism after the abolition of slavery, decades to pass equal voting rights for women and minorities, and decades to pass and enforce equal protection laws for the disabled, women, and homosexuals. As a society, we are slow learners. We tend, unfortunately, to follow our intuition, personal belief systems, and historical standards of religiously-inspired moral behavior, while ignoring evidence that contradicts them.

But I digress. With regard to the subject of this article, there is a great and ever growing body of empirical evidence that the answer to the problem of drug use and abuse lies in liberalizing current drug policy while passing reasonable regulation and control. And it does appear that, given the most recent polling data and various state drug law liberalization reforms, we are, after all, slowly learning the hard way.

\section{Special Note}

On the very day I submitted this article for final publication after peer review, September 11, 2014, the Global Commission on Drug Policy published its report "Taking Control: Pathways to Drug Policies that Work" (2014). The commission members agree with the thesis of this paper that the War on Drugs is bad public policy, ${ }^{12}$ doing far more harm than good, but also that ending the war would be the beginning of the end of drug-related violence worldwide, noting especially that the war has fueled crime and enriched criminals, undermined development and security, threatened public health and safety, and wasted billions of dollars while undermining economies (Global Commission on Drug Policy: 14).

I was particularly pleased that the commission used the word "pragmatic" as I have in this article to describe a responsible approach to drug liberalization, regulation, and control. Among the commission's specific recommendations are to put people's health and safety first, end the criminalization and incarceration of people who use drugs, and regulate drug markets to put governments in control (2). The report is exceedingly well written, clear, and unequivocal in its conclusions. It is available online in PDF format (see Bibliography below).

\footnotetext{
${ }^{12}$ Commission members include Kofi Annan, Richard Branson, Aleksander Kwasniewski, George Papandreou, George Schultz, Mario Vargas Llosa, Paul Volcker, and Fernando Henrique Cardoso (Chair), among many other luminaries.
} 
The next potentially paradigm-shifting event on the horizon with regard to the global war on drugs is the 2016 United Nations General Assembly Special Session on the World Drug Problem (UnGASs). The un has traditionally been pro-strict enforcement, but in the face of the massive body of evidence against this approach, it will be fascinating to see what unfolds.

\section{BIBLIOGRAPHY}

Alexander, M.

2010 The New Jim Crow: Mass Incarceration in the Age of Colorblindness, New York, The New Press.

Anderson, T.

1995 The Movement and the Sixties, London, Oxford University Press.

AP (Associated Press)

2010 “AP IMPACт: After 40 Years, \$ 1 trillion, US War on Drugs Has Failed to Meet Any of Its Goals," www.foxnews.com/world/2010/05/13/ap-impact-years -trillion-war-drugs-failed-meet-goals /, accessed December 12, 2013.

Armentano, P.

2009 “Study Says It's Easier for Teens to Buy Marihuana than Beer," August 28, http: / / blog.norml.org/2009/08/28 / study-says-its-easier-for-teens-to-buy -marihuana-than-beer /, accessed January 3, 2014.

\section{AstorgA, L.}

2004 “Géopolitique des drogues au Mexique," Hérodot vol. 1, no. 112, 2004.

2003 "Drug Trafficking in Mexico: A First General Assessment," Management of Social Organizations, Discussion Paper, no. 36, http:/ / www.unesco.org/most/ astorga.htm, accessed August 28, 2014.

Blocker, J., D. FAHEY, and I. TYrReLL, eds.

2003 Alcohol and Temperance in Modern History: An International Encyclopedia, Santa Barbara, Calif., ABC-CLIO. 
Centers for Disease Control

2011 "Alcohol as Third Leading Preventable Cause of Death in U.S.," http:// www.cdc.gov / chronicdisease / resources / publications / aag/alcohol.htm, accessed January 3, 2013.

Cole, J.

2014 "End the Prohibition of Heroin," The Boston Globe, August 24, http: / www .bostonglobe.com/opinion/2014/08/24/end-prohibition-heroin/, accessed August 26, 2014.

Cowen, T., and A. TABARrock

2009 Modern Principles of Economics, $1^{\text {st }}$ ed., New York, Worth Publishers.

DeITCH, R.

2003 Hemp-American History Revisited, New York City, Algora Publishing.

DVORACK, J.

2004 “America's Harried Hemp History," Hemphasis Magazine, http:/ / www .hemphasis.net/History/harriedhemp.htm, accessed December 31, 2013.

EARLYWINE, M.

2002 Understanding Marihuana: A New Look at the Scientific Evidence, New York, Oxford University Press.

ELLISON, J.

2014 “CNN Poll Reflects New Norm-Americans Support Legal Marihuana," Seattle Post Intelligencer, January 6, http: / / blog.seattlepi.com/marihuana / 2014 / 01 / 06 / cnn-poll-reflects-new-norm-americans-support-legal-marihuana / \#19405101=0, accessed January 10, 2014.

emcdda (European Monitoring Centre for Drugs and Drug Addiction)

2008 Toward a Better Understanding of Drug Related Expenditure in Europe, http: / / www .emcdda.europa.eu/publications/ selected-issues, accessed July 15, 2014.

Escohotado, A.

1999 A Brief History of Drugs: From the Stone Age to the Stoned Age, Rochester, New York, Park Street Press. 
FANG, L.

2012 Republic Report: Investigating How Money Corrupts Democracy, http:/ / www .republicreport.org/2012/marihuana-lobby-illegal/, accessed January 4, 2014.

GABLE, R.

2006 “The Toxicity of Recreational Drugs," American Scientist, vol. 94, no. 3.

Global Commission on Drug Policy

2014 Taking Control: Pathways to Drug Policies that Work, http: / / static.squarespace .comstatic/53ecb452e4b02047c0779e59 / t / 540da6ebe4b068678cd46df9 / 1410180843424/global_commission_EN.pdf, accessed September 11, 2014.

GoOdE, E.

2008 Drugs in American Society, $7^{\text {th }}$ ed., New York, McGraw-Hill.

Governing OUtLOOK

2014 www.governing.com/gov-data/state-marihuana-laws-map-medical-recre ational.html, accessed January 12, 2014.

Greenwald, G.

2009 Drug Decriminalization in Portugal: Lessons for Creating Fair and Successful Drug Policies, Washington, D.C., CATO Institute.

GROFF, M.

2012 "Questions on the 1315 Project Chart," http:/ / www.mattgroff.com/ques tions-on-the-1315-project/ chart, accessed August 22, 2013.

Hallam, C.

2010 "What Can We Learn from Sweden's Drug Policy Experience?" The Beckley Foundation Drug Policy Programme, Briefing Paper 20, January, http: / www .beckleyfoundation.org/pdf/BriefingPaper_20.pdf, accessed July 15, 2014.

Holland, J.

1997 The Pot Book: A Complete Guide to Cannabis: Its Role in Medicine, Politics, Science, and Culture, New York, Park Street Press. 
International Centre for Prison Studies

2010 World Prison Brief, United States, data base, www.prisonstudies.org/coun try / united-states-america, accessed November 23, 2013.

KENT, S.

2013 “Draconian Singapore Has Low Rate of Drug Use," Toronto Sun, July 14, http: / / www.torontosun.com / 2013 / 07 / 14 / draconian-singapore-has-low -rate-of-drug-abuse, accessed July 15, 2014.

KNUFKEN, D.

2010 “The World's Most Lucrative Business Markets," Business Pundit, May 26, citing the United Nations on Drugs and Crime, http: / / www.businesspundit.com / the-worlds-most-lucrative-business-markets / , accessed December 1, 2013.

Leap (LaW Enforcement Against Prohibition)

2012 http:// www.leap.cc/, accessed January 2, 2014.

LIBERTARIAN PARTY

2008 “National platform adopted at Denver L.P. Convention,” May 30, http:/ / www. ontheissues.org/celeb/Libertarian_Party__Drugs.htm), accessed November 1, 2013.

LIND, D.

2014 "Almost half of all federal drug prisoners could get out of prison sooner. Here's how," Vox, July 18, http:/ / www.vox.com/2014/7/18/5915611/sen tencing-retroactivity-drugs-war-reform-prison-criminal-justice?/, accessed July 22, 2014.

LINDESMITH, A.

1965 Addiction and Opiates, New Brunswick, New Jersey, Transaction Publishers.

LOPEZ, G.

2014 "The case for decriminalizing heroin, cocaine, and all other drugs," Vox, July 14, http: / / www.vox.com / 2014 / 7 / 14 / 5889293 / war-on-drugs-case-against-de criminalization-cocaine-heroin/in/5653520, accessed July 22, 2014.

Maisto, S., M. Galizio, and G. ConNors

2007 Drug Use and Abuse, $4^{\text {th }}$ ed., New York, Wadsworth Publishing. 


\section{MCWiLLIAM, J.}

1990 The Protectors: Harry J. Anslinger and the Federal Bureau of Narcotics: 1930-1962, Newark, University of Delaware Press.

MERLin, M.

2003 "Archaeological Evidence for the Tradition of Psychoactive Plant Use in the Old World," Economic Botany, vol. 57, no.3, pp. 295-323.

Miron, J., and J. ZwIEBEL

1991 "Alcohol Consumption during Prohibition," The American Economic Review, vol. 1, no. 2, Papers and Proceedings of the Hundred and Third Annual Meeting of the American Economic Association, p. 242.

Mokdad, A., J. Marks, D. Stroup, and J. L. Gerberding

2004 "Actual Causes of Death in the United States, 2000," Journal of the American Medical Association, G225, vol. 291, no. 10, p. 1242.

mpr (Marijuana Policy Project) 2013 California

2013 http: / / www.mpp.org/states / california /, accessed January 12, 2013.

\section{NORTHERn TERritory GOVERNMENT}

2008 "Alcohol and Other Drugs," http:/ / www.nt.gov.au/health/healthdev/ health _promotion/bushbook/volume2/chap1/sect1.htm, accessed January 3, 2014.

NutT, D., L. KING, and L. PhILLIPS

2010 "Drug Harms in the UK: a Multicriteria Decision Analysis," Lancet 376, pp. 1558-1565, http:/ / www.sg.unimaas.nl/_OLD/oudelezingen/dddsd.pdf, accessed December 3, 2013.

Office of National Drug Control Policy

2013 The National Drug Control Budget: FY 2013 Funding Highlights, http: / / www .whitehouse.gov/ ondcp/ the-national-drug-control-budget-fy-2013-fundinghighlights, accessed August 22, 2014.

Olives, G.

2012 “Una frágil tregua: el debate sobre la marihuana (cannabis) en los Estados Unidos dentro del contexto de conflicto entre las leyes estatales y federales," Revista Académica, Facultad de Derecho de la Universidad La Salle, year 9, no. 18, February, p. 64. 
Olivier, A.

1999 "Justice," Long Beach Press-Telegram, March 23, http:/ / digital.library.ucla.edu / websites/2006_995_110/issues009.html, accessed April 22, 2014.

ON THE ISSUES

2008 "The Libertarian Party on Drugs," http:/ / www.ontheissues.org/celeb/Lib ertarian_Party_Drugs.htm, accessed July 16, 2012.

PAulozzi, L.

2006 “Opioid Analgesic Involvement in Drug Abuse Deaths in American Metropolitan Areas," American Journal of Public Health, vol. 96, no. 10, October, pp. 1755-1757.

ROBERT, S.

2006 “The Toxicity of Recreational Drugs," American Scientist, vol. 94, no. 3, p. 207.

SAMORINI, G.

2000 Psychedelics: The Natural World and the Instinct to Alter Consciousness, New York, Park Street Press.

SCHLOSSER, E.

2003 Reefer Madness, New York, Houghton Mifflin.

SEABORNE, J.

2012 "Response to Drug Free America Foundation Recent Claims," The Florida Times Union, January 8, http: / jacksonville.com/opinion/blog/504830/ sea bourne / 2012-01-08 / response-drug-free-america-foundation-recent-claims, accessed March 4, 2014.

Substance Abuse and Mental Health Services Administration

2012 Results from the 2011 National Survey on Drug Use and Health: Summary of National Findings, NSDUH Series H-44, HHS Publication no. (SMA) 12-4713.

THORNTON, M.

1991 "Alcohol Prohibition Was a Failure," Cato Institute Policy Analysis, no. 157, www.cato.org/pubs / pas/pa-157.html, accessed December 13, 2013. 
TONRY, M.

1995 Malign Neglect: Race, Crime and Punishment in America, New York, Oxford University Press.

un OfFice on Drugs ANd CRIME

2007 Sweden's Successful Drug Policy: A Review of the Evidence, https: / / www.unodc .org/pdf/research/Swedish_drug_control.pdf, accessed July 15, 2014.

\section{U.S. BuREAU OF THE CENSUS}

1975 Historical Statistics of the United States, Colonial Times to 1970, Washington, D.C., Government Printing Office, part 1, p. 414.

\section{usdhHs (U.S. Department of Health and Human Services)}

2011 Results from the 2010 National Survey on Drug Use and Health: Summary of National Findings, NSDUH Series H-41, HHs Publication no. (sMA) 11-4658. Rockville, Maryland, Substance Abuse and Mental Health Services Administration, http: / / store.samhsa.gov/ home, accessed January 7, 2014.

\section{U.S. WAR ON DRUGS 1969-2009}

2009 Conference Summary, http: / / warondrugsconference.utep.edu/ conference\% 20summary.htm, accessed January 3, 2014.

VALKOV, N., ed.

2010 "Marihuana Abuse," Research Report Series, National Institute of Health, U.S. Department of Health and Human Services, p. 2.

WARNER, J.

2008 “U.S. Leads World in Illegal Drug Use," Substance Abuse and Addiction Health Center, http:/ / www.webmd.com/mental-health/addiction/news / 20080630 / us-leads-the-world-in-illegal-drug-use, accessed January 6, 2013.

WDR (WORLD DRUG REPORT)

2013 United Nations Office on Drugs and Crime, p. iii, http:/ / www.unodc.org/ unodc/secured/wdr/wdr2013/World_Drug_Report_2013.pdf, accessed December 10, 2013.

2011 United Nations Office on Drugs and Crime, https: / / www.unodc.org/docu ments / data-andanalysis / WDR2011/World_Drug_Report_2011_ebook.pdf, accessed January 9, 2013. 
WeB, I., T. Kerr, B. NosyK et al.

2013 "The temporal relationship between drug supply indicators: an audit of international government surveillance systems," British Medical Journal Open 3:e003077, pp. 2-3, http: / / www.bmjopen.bmj.com/content/3/9/e003077.full .pdf.html, accessed January 3, 2014.

WING, N.

2013 “These States Are Most Likely to Legalize Pot Next," The Huffington Post, August 31, http:/ / www.huffingtonpost.com/2013/08/30/ marihuana-legaliza tion-states_n_3838866.html, accessed December 12, 2013.

WODAK, A.

2012 "Drug law reform when bad policy is good politics," The Lancet, November 5, http: / / www.idhdp.com/mediaimport / 25067 / drug_law_reform_when _bad_policy_is_good_politics.pdf, accessed July 22, 2014. 